\title{
The distribution of muramidase (lysozyme) in human tissues
}

\author{
D. Y. MASON AND C. R. TAYLOR
}

From the Department of Pathology, Gibson Laboratories, Radcliffe Infirmary, Oxford

SYNOPSIS The distribution of muramidase (lysozyme) in normal and pathological human tissueso has been studied, using an immunohistological technique. The enzyme was demonstrated in ai variety of healthy tissues, including serous salivary acinar cells, lactating mammary tissue, Panethi cells, renal tubular cells, myeloid cells (including eosinophils), and histiocytic cells.

In pathological tissues the most striking positivity was encountered in reactive histiocytic cells in granulomatous conditions such as tuberculosis and Crohn's disease.

The findings of this study are related to previous reports of the distribution of human and animal ${ }^{-}$ muramidase and the implications of patterns of muramidase staining in pathological histiocytes $\frac{\Phi}{0}$ are briefly discussed.

In 1922 Alexander Fleming reported on a 'remarkable bacteriolytic' element found in tissues and secretions, and coined the name 'lysozyme' for this activity. It was subsequently established that lysozyme acts through the dissolution of $\mathrm{N}$-acetylglucosaminyl-N-acetylmuramic acid linkages in the cell walls of susceptible microorganisms, and the synonym 'muramidase' is now widely used. The enzyme is present in easily detectable amounts in human milk, tears, saliva, and serum. Moderately elevated serum levels have been reported in cases of tuberculosis, sarcoidosis, and myeloproliferative diseases (Finch, Lamphere, and Jablon, 1964; Osserman and Lawlor, 1966; Catovsky, Galton, and Griffin, 1971) while relatively enormous increases in serum and urine values are found in cases of leukaemia in which the malignant clone shows monocytic differentiation (Osserman and Lawlor, 1966). Serum muramidase in normal subjects and in patients with myeloproliferative disorders is thought to represent enzyme liberated from dying polymorphonuclear leucocytes (Fink and Finch, 1968), while the elevated levels in granulomatous diseases and in leukaemia appear to reflect liberation from, respectively, tissue histiocytes and from myelomonocytic cells (Catovsky et al, 1971). Muramidase in tears, saliva, and other secretions probably represents synthesis by glandular cells.

Attempts to localize the cellular origins of human muramidase have been hampered by the lack of a

Received for publication 16 October 1974. simple and accurate histological technique forv detecting the enzyme. Methods hitherto describsdo have either exploited the saccharolytic properties $\overline{\text { ôf }}$ the enzyme, using Micrococcus lysodeikticus or chitin as a substrate, or have relied on the use of labelled antibodies. Neither of these approaches $\Phi$ has allowed full examination of muramidase distribution in human tissues (table I). The former methods suffer from the disadvantage that the mura- $\frac{3}{2}$ midase must still be enzymatically active when the tissue is tested, ie, tissue must be fresh and unfixed. Immunological techniques, on the other hand, whilst not requiring the preservation of enzyme activity, $\overline{-}$ are also considered incompatible with formalin fixation. Thus Asamer, Schmalzl, and Braunsteinero (1971) used alcohol-fixed blood and bone marrow smears; while Erlandsen and Parson (1973) and 음 Sternberger, Hardy, Cuculis, and Meyer (1970a) $\supset$ examined respectively glutaraldehyde- and osmiumfixed tissues. Immunofluorescent techniques have N the additional disadvantage of poor tissue and ${ }^{\circ}$ cellular morphology, particularly in comparison 0 with the excellent histological results which can be $\underset{\omega}{N}$ achieved by immunoperoxidase methods (Taylor 0 and Burns, 1974; Burns, Hambridge, and Taylor, 0 1974; Taylor and Mason, 1974).

The present report describes the use of immuno- $\stackrel{?}{?}$ histological techniques for specifically staining $?$ human muramidase. These methods utilize peroxi-웅 dase-conjugated antibodies, or immune complexes $\stackrel{\Phi}{\Phi}$ of peroxidase with rabbit antibody to peroxidase $\stackrel{\mathbb{\Omega}}{\stackrel{\mathbb{Q}}{2}}$ (PAP), and are applicable to all formalin-fixed. 


\begin{tabular}{|c|c|c|}
\hline Author & Technique & Site \\
\hline Briggs et al (1966) & Lysis of micrococcus & Myeloid cells and monocytes \\
\hline Ghoos and Vantrappen (1970) & Hydrolysis of chitin & Neutrophils \\
\hline Sternberger et al (1970b) & Electron immunocytochemistry & $\begin{array}{l}\text { Leukaemic monocytes and normal and } \\
\text { leukaemic granulocytes }\end{array}$ \\
\hline Asamer et al (1971) & Immunofluorescence & Leukaemic myeloid and monocytic cells \\
\hline Syren and Raeste (1971) & Lysis of micrococcus & Neutrophils and monocytes \\
\hline Scholnik and Kass (1973) & Hydrolysis of chitin & Neutrophils and leukaemic blast cells \\
\hline Catovsky and Galton (1973) & Lysis of micrococcus & Myeloid leukaemic blast cells \\
\hline Erlandsen and Parson (1973) & Immunoperoxidase & Paneth cells in small intestine \\
\hline
\end{tabular}

Table I Reported distribution of human muramidase (lysozyme)

paraffin-embedded tissues, even after prolonged storage. Preliminary studies by these methods have provided information on the distribution of muramidase in normal tissues and have revealed findings of particular interest in some disease states.

\section{Materials}

\section{TISSUES}

Paraffin-embedded blocks of several different tissues were selected from the surgical histology files at the Radcliffe Infirmary. Tissues had been routinely processed on the laboratory Histokinettes by the recommended schedule, using industrial methylated spirit and chloroform following adequate formalin fixation.

\section{BLOOD SMEARS}

Buffy coat smears were prepared from fresh EDTA samples of normal human blood, air dried, and fixed for five minutes in absolute ethanol.

\section{ANTIMURAMIDASE ANTISERA}

Two antisera were used. The first was prepared by immunizing a rabbit with human muramidase isolated from the urine of a chronic monocytic leukaemic patient. After batch absorption of the urine with CM-60 Sephadex, and repeated washing of the Sephadex with $0.05 \mathrm{M}$ Tris $\mathrm{HCl}$ buffer, $\mathrm{pH}$ $7 \cdot 0$, muramidase was eluted with $2 \mathrm{M}$ Tris $\mathrm{HCl}$ buffer, $\mathrm{pH} 7 \cdot 0$. The resulting preparation of muramidase (MX 1) was dialysed extensively against distilled water, and freeze dried. Cellulose acetate and SDS-acrylamide gel electrophoresis showed a single homogeneous protein band. However, on Ouchterlony testing of concentrated MX 1, weak reactions were obtained with anti-IgG, anti-kappa, and anti-lambda antisera, indicating the presence of small amounts of polyclonal IgG. This contaminant was removed by column filtration through Sephadex G-75 giving a preparation (MX 2), which produced no reactions on Ouchterlony testing with anti-IgG, anti-kappa, or anti-lambda antisera.

A rabbit was immunized intramuscularly with
MX 1 in complete Freund's adjuvant on days 1 and 8 followed by a booster injection of MX 2 on day 83, with bleeding on days 92 and 97 . The resulting pooled antiserum was tested by immunoelectrophoresis and found to contain a potent antibody to human muramidase, together with activity against human immunoglobulin. The latter component was removed by precipitation with purified human IgG, and an ammonium sulphate immunoglobulin fraction of the antiserum was prepared. Before use the antibody was absorbed twice with glutaraldehyde insolubilized normal human serum.

The second rabbit antimuramidase antiserum, together with all other antisera used in the study, was obtained from Dakopatts A/S (UK agents, Mercia Diagnostics, Sandown Road, Watford, England). The PAP (peroxidase-anti-peroxidase complexes) was prepared by Dr Agnette Ingild of Dakopatts A/S according to Sternberger's original method (Sternberger et al, 1970).

\section{Methods}

Serial sections were cut at $5 \mu$, dewaxed with xylol and processed to absolute alcohol (ethanol). Blood

\begin{tabular}{|c|c|}
\hline $\begin{array}{l}\text { Stage } \\
\text { No. }\end{array}$ & Procedure \\
\hline 1 & $5 \mu$ paraffin section-xylol-absolute ethanol \\
\hline 2 & $\begin{array}{l}\text { Block endogenous peroxidase with methanol containing } \\
0.3 \% \text { hydrogen peroxide: } 30 \text { minutes }\end{array}$ \\
\hline 3 & Normal swine serum 1/20:10 minutes ${ }^{2}$ \\
\hline 4 & Rabbit antimuramidase $1 / 10: 30$ minutes \\
\hline 5 & $\begin{array}{l}\text { Swine antirabbit serum IgG conjugated with horseradish } \\
\text { peroxidase } 1 / 20: 30 \text { minutes }\end{array}$ \\
\hline 6 & $\begin{array}{l}\text { Diamino-benzidine (D.A.B. }{ }^{2} \text { ) reaction, counterstain with } \\
\text { haematoxylin, dehydrate, mount in DPX }\end{array}$ \\
\hline
\end{tabular}

Table II Peroxidase conjugate method ${ }^{1}$

${ }^{1}$ All reactions carried out in Tris buffer (pH 7.6), washes after stages $2,3,4$ and 5 in Tris saline (a 1/10 dilution of Tris buffer with normal saline).

${ }^{2}$ Stage 3 is optional and is designed to reduce unwanted 'background' staining.

${ }^{3}$ D.A.B. $33^{\prime}$ Diamino-benzidine tetrahydrochloride (BDH Chemicals, Poole, England) $6 \mathrm{mg}$ in $10 \mathrm{ml}$ of Tris buffer containing freshly added hydrogen peroxide $0.01 \%$. 


\begin{tabular}{ll}
\hline $\begin{array}{l}\text { Stage } \\
\text { No. }\end{array}$ & Procedure \\
\hline 1 & $5 \mu$ paraffin section-xylol-absolute ethanol \\
2 & Block endogenous peroxidase with methanol containing \\
& $0 \cdot 3 \%$ hydrogen peroxide 30 minutes \\
3 & Normal swine serum $1 / 20: 10$ minutes \\
4 & Rabbit antimuramidase $1 / 40: 30$ minutes \\
5 & Swine antirabbit serum protein $1 / 20: 30$ minutes \\
6 & PAP (peroxidase anti-peroxidase complexes) $1 / 20: 30$ minutes \\
7 & Diamino-benzidine (DAB ${ }^{3}$ reaction, counterstain with \\
& haematoxylin, dehydrate, mount in DPX \\
\hline
\end{tabular}

Table III The PAP (peroxidase-anti-peroxidase immune complex) method ${ }^{1}$

${ }^{1}$ All reactions in Tris buffer ( $\mathrm{pH} 7 \cdot 6$ ), all washes after stages $2,3,4,5$, and 6 in Tris saline.

2Stage 3 optional.

${ }^{3}$ DAB $33^{\prime}$ diamino-benzidine tetrahydrochloride (BDH Chemicals, Poole, England) $6 \mathrm{mg}$ in $10 \mathrm{ml}$ of Tris buffer containing freshly added hydrogen peroxide $0.01 \%$.

smears were allowed to dry after ethanol fixation and subsequently treated in the same way as tissue sections. All slides were transferred to absolute methanol containing $0.3 \%$ hydrogen peroxide in order to block the endogenous peroxidase activity (of granulocytes and red cells) which interferes with the interpretation of results (see Burns et al, 1974). The subsequent method is summarized in tables II and III.

All tissues were initially examined by the "peroxidase conjugate' method (table II and Taylor and Burns, 1974). Those tissues in which results were equivocal were subsequently re-examined by the more sensitive PAP method (table III and Taylor, 1974). In this procedure the tissue-bound rabbit antiserum to muramidase (stage 4 , table III) is linked to the rabbit antiserum against horseradish peroxidase in the PAP complex (stage 6, table III) by the intermediate addition of a swine antiserum to rabbit serum protein (stage 5, table III). Background staining was minimal by this method due to the intrinsic purity of the PAP, and the higher dilution factor of the antimuramidase antiserum.

Troublesome background staining in the peroxidase conjugate method may be reduced by pretreatment of sections with normal swine serum. This reduces non-specific absorption of antisera and avoids cross reaction with the swine anti-immunoglobulin antisera used in stage 5 . In order to facilitate comparisons between the different methods all sections were subjected to 'pretreatment' with normal swine serum (stage 3, tables II and III).

In addition, all sections showing positive staining with our antimuramidase antiserum, together with the majority of the 'negative' sections, were checked by the identical procedure using Dakopatts antimuramidase. In every case results were in agreement.

\section{Controls}

Serial sections of selected cases were subjected to the procedures presented in tables II and III, with the omission of each stage in turn. Also in every case examined by anti-muramidase, a parallel section was subjected to the identical procedure, except that rabbit anti-IgM antiserum was substituted for the rabbit anti-muramidase. There was no evidence of specific staining in any of these control preparations, other than occasional IgM-containing plasma cells.

\begin{tabular}{|c|c|c|}
\hline & Tissue & Muramidase Activity \\
\hline $\begin{array}{l}\text { Normal Tissue } \\
\text { Digestive system }\end{array}$ & $\begin{array}{l}\text { Stomach } \\
\text { Small bowel } \\
\text { Colon } \\
\text { Liver } \\
\text { Pancreas }\end{array}$ & $\begin{array}{l}\text { Negative } \\
\text { Paneth cells positive' } \\
\text { Negative } \\
\text { Kupfer cells positive }{ }^{1} \\
\text { Negative }\end{array}$ \\
\hline Endocrine & $\begin{array}{l}\text { Adrenal } \\
\text { Thyroid }\end{array}$ & $\begin{array}{l}\text { Negative } \\
\text { Negative }\end{array}$ \\
\hline Genitourinary & $\begin{array}{l}\text { Testis } \\
\text { Ovary } \\
\text { Prostate } \\
\text { Kidney } \\
\text { Uterine cervix } \\
\text { Endometrium }\end{array}$ & $\begin{array}{l}\text { Negative } \\
\text { Negative } \\
\text { Negative } \\
\text { Proximal tubular cells } \\
\text { positive } \\
\text { Negative, including endo- } \\
\quad \text { cervical glands } \\
\text { Negative }\end{array}$ \\
\hline Exocrine & $\begin{array}{l}\text { Lacrimal glands } \\
\text { Salivary glands } \\
\text { Bronchial glands } \\
\text { Sebaceous glands } \\
\text { Sweat glands }\end{array}$ & 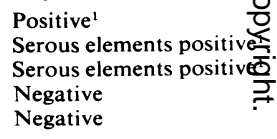 \\
\hline Mammary tissue & $\begin{array}{l}\text { Non-lactating } \\
\text { Lactating }\end{array}$ & $\begin{array}{l}\text { Negative } \\
\text { Positive }^{1}\end{array}$ \\
\hline Musculoskeletal & $\begin{array}{l}\text { Striated muscle } \\
\text { Smooth muscle } \\
\text { Myocardium } \\
\text { Cartilage }\end{array}$ & $\begin{array}{l}\text { Negative } \\
\text { Netative } \\
\text { Negative } \\
\text { Positive }^{1}\end{array}$ \\
\hline $\begin{array}{l}\text { Lymphatic and } \\
\text { haematological } \\
\text { tissue }\end{array}$ & $\begin{array}{l}\text { Lymph nodes } \\
\text { Spleen } \\
\text { Peripheral blood } \\
\text { Bone marrow }\end{array}$ & $\begin{array}{l}\text { Positive histiocytes }^{1} \\
\text { Positive histiocytes } \\
\text { Positive polymorphs and } \\
\text { monocytes } \\
\text { Positive myeloid cells }\end{array}$ \\
\hline Respiratory system & Bronchial epithelium & $\begin{array}{l}\text { Alveolar lining cells and } \\
\text { iron or carbon contain- } \\
\text { ing macrophages, nega- } \\
\text { tive } \\
\text { Mucus secreting cells }\end{array}$ \\
\hline & 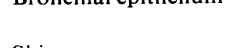 & negative \\
\hline Integument & Skin & $\begin{array}{l}\text { Sweat and sebaceous } \\
\text { glands negative }\end{array}$ \\
\hline $\begin{array}{l}\text { Pathological Tissue } \\
\text { Reactive }\end{array}$ & $\begin{array}{l}\text { Granulation tissue } \\
\text { Fat necrosis } \\
\text { Tuberculosis, sarcoi- } \\
\text { dosis, and Crohn's } \\
\text { disease }\end{array}$ & $\begin{array}{l}\text { Positive histiocytes } \\
\text { Positive giant cells }{ }^{1} \\
\text { Positive epithelioid his- } \\
\text { tiocytes and giant cells }{ }^{1}\end{array}$ \\
\hline $\begin{array}{l}\text { Lipid-containing } \\
\text { phagocytes }\end{array}$ & $\begin{array}{l}\text { Xanthoma } \\
\text { Gaucher's disease }\end{array}$ & $\begin{array}{l}\text { Positive giant cells }{ }^{1} \\
\text { Positive histiocytes }^{1}\end{array}$ \\
\hline Miscellaneous & $\begin{array}{l}\text { Histiocytoma } \\
\text { Giant cell tumour of } \\
\text { tendon sheath } \\
\text { Eosinophilic granu- } \\
\text { loma }\end{array}$ & $\begin{array}{l}\text { Negative } \\
\text { Negative } \\
\text { Positive eosinophils and } \\
\text { histiocytes }\end{array}$ \\
\hline
\end{tabular}

Table IV Distribution of muramidase in human tissues ${ }^{2}$ See text 
Incubation of the anti-muramidase antisera with a solution of purified muramidase completely abolished specific activity (see results).

\section{Results}

Morphological detail in all sections examined was excellent, equivalent to any orthodox haematoxylinand -eosin paraffin section. Positive brown staining for muramidase clearly contrasted with the blue haematoxylin counterstain.

The results of testing a variety of human tissues for muramidase activity are given in table IV. At least two examples of each tissue have been examined.

All sections contained a variable number of positive polymorph leucocytes (both eosinophil and neutrophil), and these cells provided a useful positive control, demonstrating in each case that the technique was working satisfactorily. Tissues in which only granulocytes and the occasional scattered mononuclear cells (? monocytes) stained for muramidase were classified in table IV as negative.

\section{TISSUES CONTAINING MURAMIDASE}

Small bowel

Positivity was confined to Paneth cells, all of which appeared to contain the enzyme. Activity was predominantly localized in the apex of the cells, where it outlined the membranes of the secretion granules.

\section{Liver}

Some Kupffer cells gave positive reactions, but an undefined proportion were clearly negative. There was no discernible pattern to the distribution of positive and negative cells.

\section{Kidney}

Proximal tubular cells were positive (fig 1). Tubular

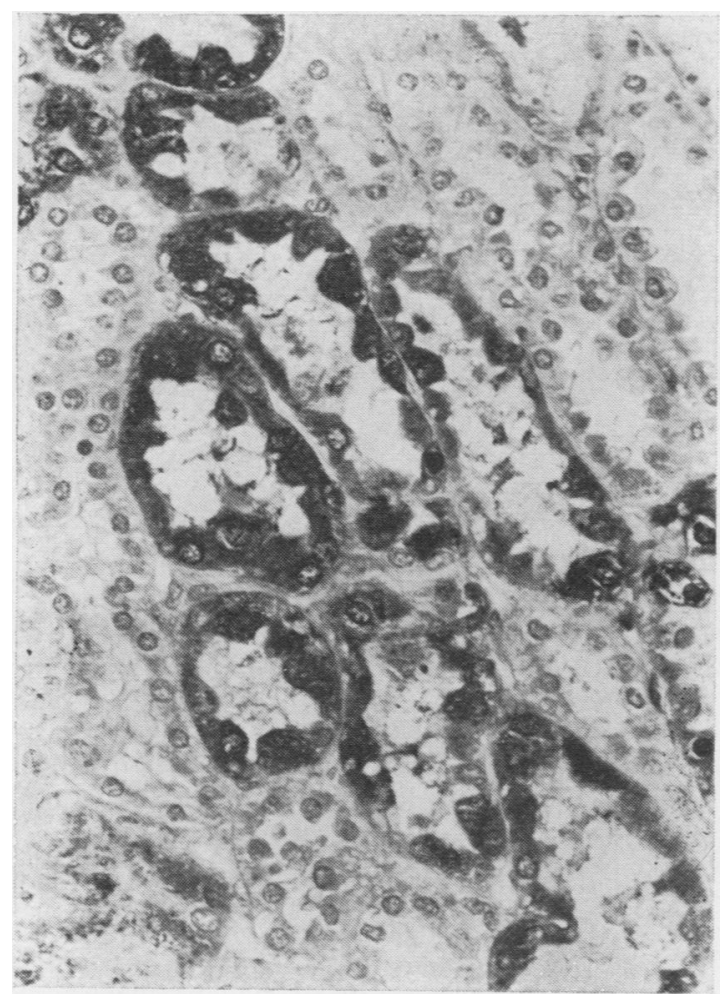

Fig 1

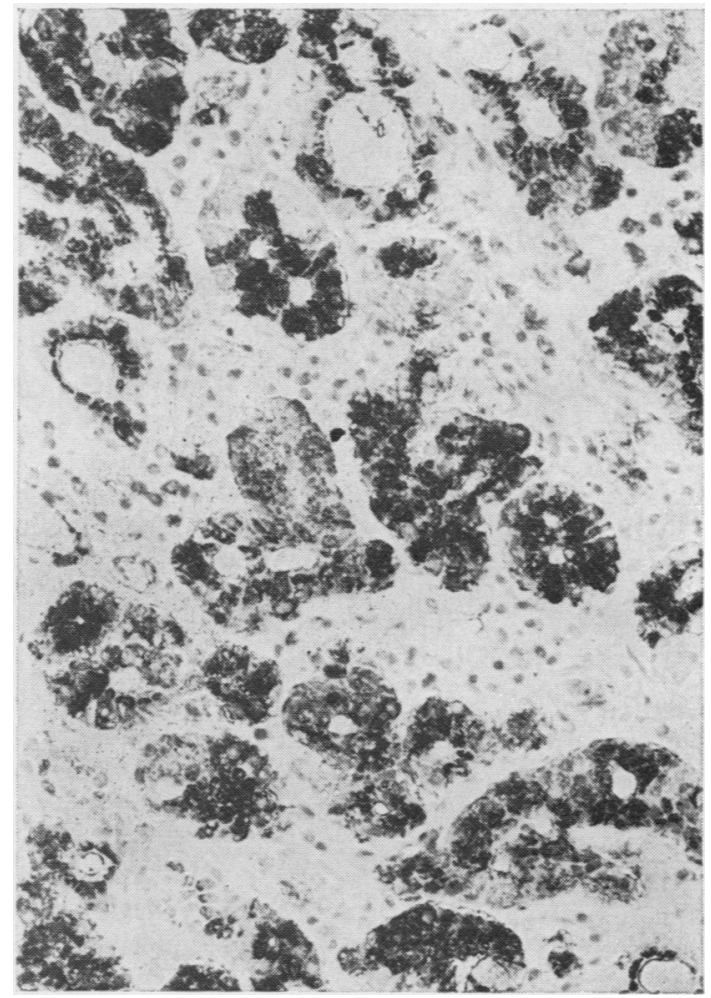

Fig 2

Fig 1 Kidney. Epithelial cells of proximal tubule clearly positive (black) distal tubule negative. Cyan blue filter $\times 750$.

Fig 2 Lacrimal glands. Positive (black) staining for muramidase in the majority of the glandular epithelial cells. Cyan blue filter $\times 750$. 


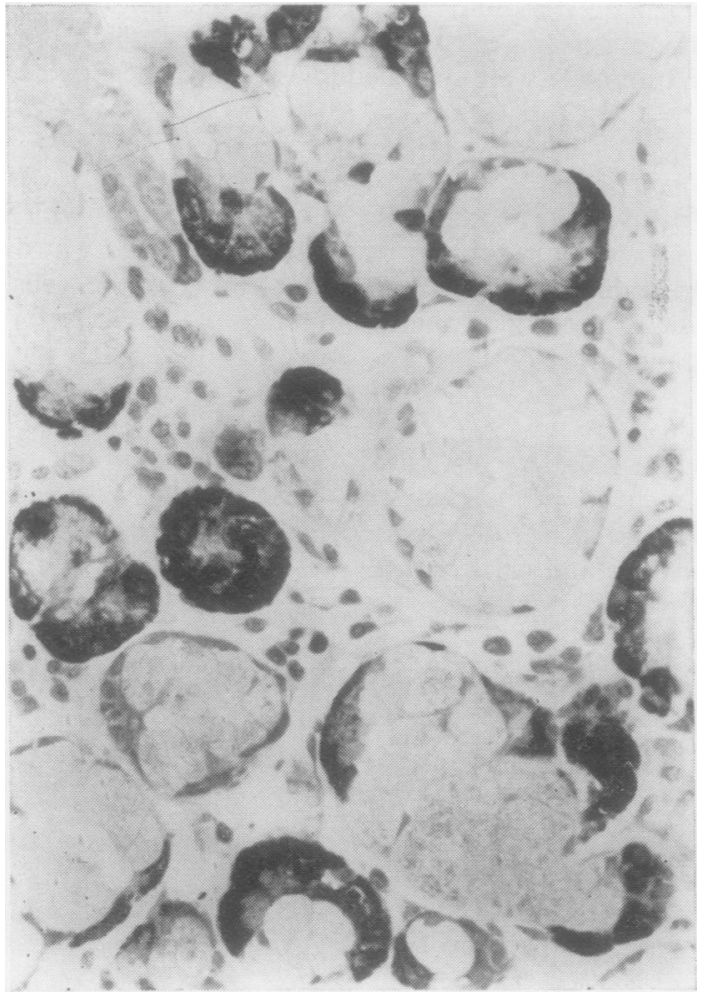

Fig 3

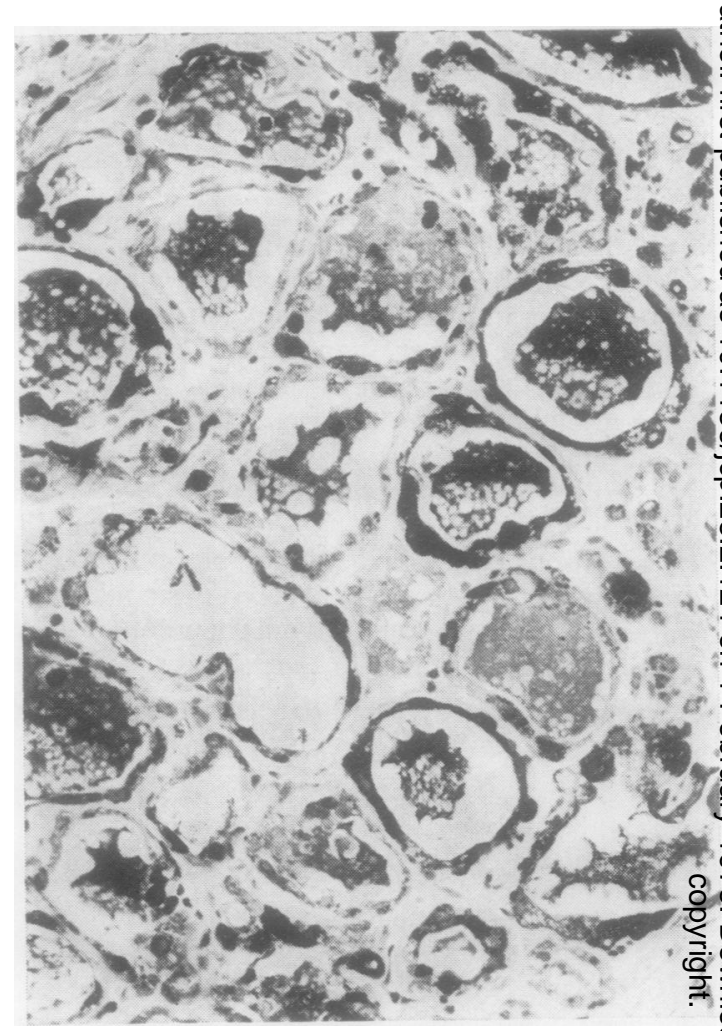

Fig 4

Fig 3 Mixed type salivary gland. Serous 'caps' or 'demilunes' clearly positive (black), mucus-secreting element negative. Cyan blue filter $\times 750$.

Fig 4 Lactating breast. Positive (black) muramidase-containing cells line the secretory acini. Secretions themselves show diffuse positive staining. Cyan blue filter $\times 750$.

cells in the upper part of the descending limb of Henle's loop were less strongly positive, and the reaction disappeared as the loop progressed into the medulla.

\section{Lacrimal glands}

The majority of the glandular acini were strongly positive (fig 2). A few acini, and the ducts of the gland, contained no demonstrable muramidase.

\section{Salivary glands}

Mucous gland acini were consistently negative. In the accessory mixed-type glands underlying the buccal mucosa, 'caps' of serous cells were clearly positive (fig 3). The parotid gland, although an almost pure serous gland, contained no activity.

\section{Bronchial glands}

An appearance very similar to that of mixed salivary glands was seen, with positive serous 'caps' to many mucous acini.

\section{Lactating breast}

Many of the flattened epithelial cells lining dilated secretory acini were strongly positive (fig 4), a were the secretions within the acini. In all of the acini negative cells could be found lying adjacent tô morphologically identical muramidase-containing cells.

\section{Cartilage}

Faint diffuse granular staining of cartilage was observed, together with strong staining in lacunae

\section{Lymphatic tissue}

The appearances varied greatly according to the्ष degree of reactivity of the lymphoreticular tissue. In quiescent lymph nodes the small germinal centres 
were entirely negative. In addition, there was no evidence of positive reaction in sinus lining cells or in paracortical or sinus histiocytes.

In follicular hyperplasia a proportion of tingible body macrophages showed distinct positivity, while in other cases morphological 'dendritic reticular cells' in the peripheral parts of the follicles appeared positive. In sinus histiocytosis an increasing proportion of sinus histiocytes showed positive staining of marked intensity, and small aggregations of histiocytes in paracortical areas showed similar reactions. These features were observed in 'dermatophathic lymphadenitis' and in lesser degrees of non-specific histiocytosis.

The most marked positive reactions, however, were seen in lymph nodes containing tuberculous or Kveim-positive sarcoid lesions. An essentially identical pattern of numerous strongly positive epithelioid histiocytes and giant cells was seen in both these conditions (fig 5). However it was always possible, even in the most active granulomata, to see negative cells of similar morphology.

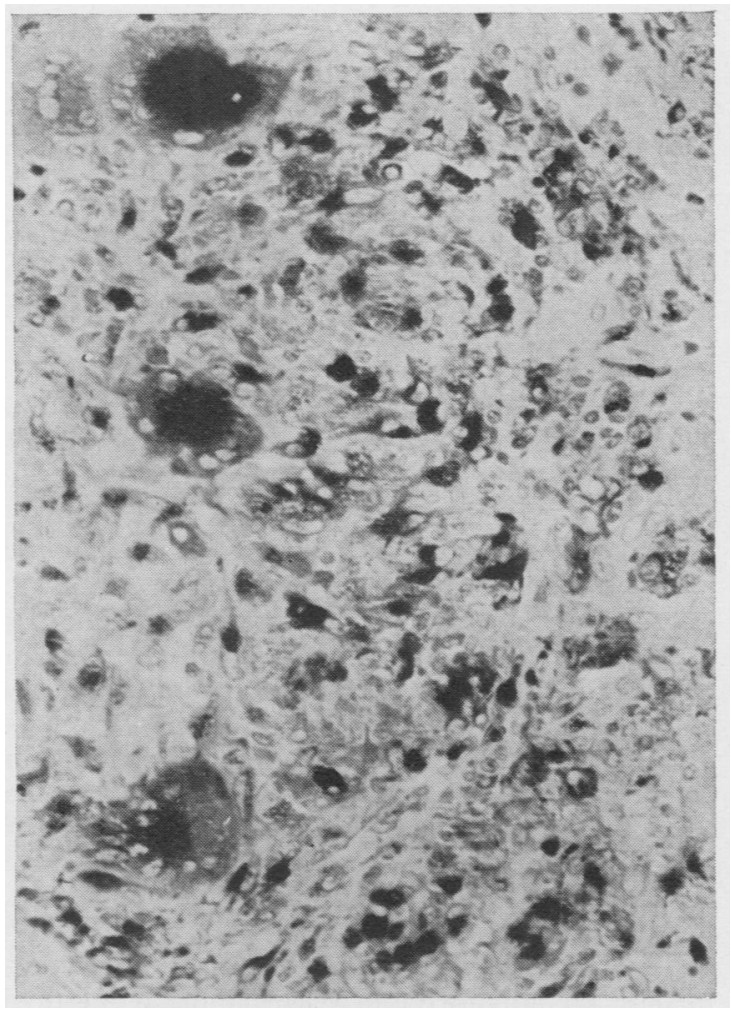

Fig 5 Sarcoidosis. Epithelioid granuloma with positive (black) and negative histiocytes and three strongly positive giant cells. Cyan blue filter $\times 750$.
In areas of healthy lymphoid tissue adjacent to granulomata there were numerous strongly positive smaller histiocytes, possibly migrating towards the diseased regions.

Granulomata in samples of bowel affected by Crohn's disease were also found to contain numerous strongly positive histiocytic cells.

\section{Peripheral blood}

In alcohol-fixed buffy coat smears intense cytoplasmic staining was apparent in all but a very few neutrophils. Monocytes stained less strongly, and in a proportion no enzyme was detectable.

\section{Bone marrow}

Sections of bone marrow revealed large numbers of muramidase-positive cells. The majority of these were morphological neutrophils, or eosinophils, or recognizable segmented precursors. A proportion of 'mononuclear' cells were also positive, but it is not yet clear whether these represent more primitive granulocytic cells or monocytoid cells.

\section{Granulation tissue}

In granulation tissue from the base of a peptic ulcer the majority of cells (including histiocytes and fibroblasts) were negative. In areas where acute inflammatory cells were present, a few histiocytes showed granular positivity.

\section{Fat necrosis}

A minority of the giant cells found in association with cholesterol clefts were faintly positive.

\section{Lipid-containing phagocytes}

A proportion of Gaucher's histiocytes, and a few giant cells in one of the two xanthomata examined stained weakly and diffusely for muramidase. In the latter instance the positive reaction for muramidase was associated with other features of chronic irritation, possibly the result of minor trauma.

\section{Eosinophilic granuloma}

The eosinophil polymorphs which are a striking feature of this condition showed strong granular positivity. In addition scattered foamy histiocytes contained moderate amounts of the enzyme. The majority of other histiocytic cells, which tended to be smaller, were negative or very weakly positive.

SPECIFICITY OF MURAMIDASE STAIN

The antimuramidase antiserum was diluted $1 / 20$ in a $1.0 \mathrm{mg} / \mathrm{ml}$ solution of purified muramidase (MX 2), and applied to several sections in which muramidasepositive cells appeared to be numerous. In each case the positive staining was completely abolished, 
confirming the specificity of the reaction for muramidase.

\section{Discussion}

The present investigation confirms most of the previously reported work on the cellular distribution of human muramidase, in that normal myeloid and monocytic cells contained the enzyme. A single discrepancy lies in the fact that we found strong muramidase activity in mature eosinophils in tissue sections but not in blood films. This possibly reflects differences in the methods of processing for sections and smears. Three other reports have suggested that there is little or no enzyme in eosinophils in smears (Scholnik and Kass, 1973; Briggs, Perillie, and Finch, 1966; Syren and Raeste, 1971).

Studies of human muramidase (quoted in table I) have been supplemented by investigations of muramidase activity in animal tissues, and the present survey may be considered in relation to this work. Because of the species antigenic specificity of muramidase, we have not been able to apply the immunoperoxidase technique to tissue of non-human origin.

\section{RENAL TUBULAR CELls}

The enzyme has been demonstrated in rat and mouse proximal tubular cells (Glynn and Parkmann, 1964; Klockars and Osserman, 1974), a finding which was confirmed for man in the present study. The kidney is known to excrete muramidase readily into the glomerular filtrate, whence it is reabsorbed and catabolized by proximal tubular cells (Balazs and Roepke, 1966).

\section{LACRIMAL GLAND}

Fleming, in his original paper on muramidase, described powerful activity in human tears, and our present findings demonstrate that the majority of the secretory cells of the lacrimal gland are capable of muramidase synthesis. Scholnik and Kass (1973) had previously found muramidase activity in rabbit lacrimal glands. However, Klockars and Osserman (1974) discovered an apparent species difference in that rat lacrimal tissue was devoid of this enzyme.

\section{CARTILAGE}

Muramidase has been detected in chick and human rat cartilage (Kuettner, Eisenstein, Soble, and Arsenis, 1971; Greenwald and Sajdera, 1971; Greenwald, Josephson, Diamond, and Tang, 1972). In all these studies muramidase was found to be extracellular. Kuettner et al (1971), using an immunofluorescent technique, showed localization around chondrocyte lacunae, an appearance similar to the pattern which we encountered in human cartilage. $\stackrel{0}{=}$ It is therefore possible that cartilage muramidase is $\underline{0}$ not synthesized by the chondrocytes themselves, $\stackrel{\Rightarrow}{\Rightarrow}$ but taken up instead from tissue fluids. This concept $\stackrel{\vec{F}}{+}$ is supported by the reports of Greenwald et al (1972)을 and of Eisenstein, Arsenis, and Kuettner (1970) that exogenous muramidase, because of its strongly $\frac{D}{D}$ cationic charge, will bind to cartilage.

In contrast to these findings Klockars and Osserman (1974) could demonstrate no muramidase $\vec{\circ}$ activity in rat cartilage.

THYROID TISSUE

A further discrepancy, also possibly species related, lies in the finding by Klockars and Osserman of i muramidase in rat thyroid follicles. We could not $\stackrel{\infty}{\sim}$ demonstrate even weak activity in human thyroid sections.

SALIVARY GLANDS, BRONCHIAL GLANDS, AND LACTATING BREAST

We could find no record that muramidase has been detected in these organs previously, although both human saliva and milk have long been known to contain the enzyme. The observation that serous $\vec{\theta}$ elements in the parotid were negative was of interest or and accords with Klockars and Osserman's obse vation on rat parotid tissue.

PANCREAS

We found no evidence of pancreatic muramidase $\stackrel{\circ}{\varnothing}$ activity, in contrast to the report by Speece (1964) that the enzyme is present in mouse pancreatic tissue. 을

INTESTINAL CELLS

Paneth cells were found to be strongly positive in the present study, in accordance with the reports of Erlandson and Parson (1971) on human tissue, by Klockars and Osserman (1974) on rat small intestine, and by Ghoos and Vantrappen (1971) on mouse $ᄋ$ jejunum. The function of Paneth cells is unknown. Klockars and Osserman (1974) cite the large number응 of Paneth cells in the small intestine of the Brazilian $>$ ant-bear as evidence that they were originally․ㅡㄹ. evolved for the secretion of chitin-dissolving mura-n midase. An alternative view, that they function? primarily as fixed phagocytes, is supported by the ${ }^{N}$ work of Erlandson and Chase (1972) in which rat $\mathrm{N}_{\mathrm{E}}$ Paneth cells were shown to be actively phagocytico for two different species of intestinal microorganismo

Klockars and Osserman also reported that rat colonic and rectal epithelial cells contained mura $-\stackrel{5}{?}$ midase. We initially found weak staining at intestinalo epithelial surfaces by the peroxidase conjugate method. This method, however, is prone to give non-specific staining at tissue interfaces, and there $\mathbb{\mathbb { D }}_{\Omega}$ 
was no suggestion of positivity using the more sensitive PAP method in which non-specific staining is greatly reduced.

\section{MACROPHAGES AND HISTIOCYTES}

It was apparent in this study that many histiocytes whether in hepatic, pulmonary, or lymphatic tissues, were negative for muramidase. These negative cells included such declared phagocytes as pulmonary 'heart failure' alveolar macrophages and carboncontaining histiocytes.

Those histiocytes or macrophages which were found to contain the enzyme fell into three categories:

\section{Morphologically unremarkable cells in normal tissues}

Scattered histiocytic cells in all tissues were occasionally strongly positive. Kupffer cells were the most frequently positive cells in this category.

\section{Storage, reactive, and giant cells}

A proportion of cells such as Gaucher's cells, xanthoma cells, and giant cells in areas of fat necrosis contained muramidase. The reaction was always weak, however, and frequently at the threshold for detection of the enzyme.

\section{Epithelioid histiocytes, activated histiocytes}

The cells, exemplified by the histiocytes seen in sarcoid, tuberculous, and Crohn's granulomata, were frequently strongly positive.

This triple hierarchy of positive cells suggests that muramidase may be synthesized predominantly in 'reactive' histiocytes, rather than in resting unstimulated phagocytes, or in cells which have ingested relatively bland substances such as lipid carbon particles or red cells. This concept is supported by Klockars and Osserman (1974) who reported negative staining in all the rat lymph nodes which they examined with the exception of a single paraaortic node in which germinal centre hyperplasia and sinus histiocytosis were associated with the presence of many muramidase-positive histiocytes. There is further evidence for the hypothesis that muramidase is synthesized only by 'activated' histiocytes in the increased serum levels found in tuberculosis and sarcoidosis (Finch et al, 1964; Osserman and Lawlor, 1966) and also in the work of Cappucino, Winston, and Perri (1964) and of Glynn (1968) who demonstrated an increase in splenic muramidase in mice receiving BCG injections.

\section{Conclusion}

The technique described here may be of value in the study of the monocyte/histiocyte series in health and in disease. Possible clinical applications include the investigation of monocytic and myelomonocytic leukaemias, particularly when the latter appears as a terminal event in cases of multiple myeloma (Andersen and Videbaek, 1970).

We are indebted to Miss Maria Hambridge for technical assistance, to Dr T. Parry and Mr T. Reed for their expert photographic work, and to Mrs $\mathrm{J}$. Braidwood for typing the manuscript. Dr A. H. T. Robb-Smith has provided valuable advice and encouragement throughout. Miss Hambridge is supported by a grant from the Leukaemia Research Fund.

\section{References}

Andersen, E., and Videbaek, A. (1970). Stem cell leukaemia in myelomatosis. Scand. J. Haemat., 7, 201-207.

Asamer, H., Schmalzl, F., and Braunsteiner, H. (1971). Immunocytological demonstration of lysozyme (muramidase) in human leukaemic cells. Brit. J. Haemat., 20, 571-574.

Balazs, T., and Roepke, R. R. (1966). Lysozymuria induced in rats by nephrotoxic agents. Proc. Soc. exp. Biol. (N.Y.), 123, 380-385.

Briggs, R. S., Perillie, P. E., and Finch, S. C. (1966). Lysozyme in bone marrow and peripheral blood cells. J. Histochem. Cytochem., 14, 167-170.

Burns, J., Hambridge, M., and Taylor, C. R. (1974). Intracellular immunoglobulins: a comparative study on three standard tissue processing methods using horseradish peroxidase and fluorochrome conjugates. J. clin. Path., 27, 548-557.

Cappucino, J. G., Winston, S., and Perri, G. C. (1964). Muramidase activity of kidney and spleen in Swiss mice challenged with B.C.G., zymosan, and bacterial endotoxins. Proc. Soc. exp. Biol. (N.Y.), 116, 869-872.

Catovsky, D., Galton, D. A. G., and Griffin, C. (1971) The significance of lysozyme estimations in acute myeloid and chronic monocytic leukaemia. Brit. J. Haemat., 21, 565-580.

Eisenstein, R., Arsenis, C., and Kuettner, K. E. (1970). Electron microscopic studies of cartilage matrix using lysozyme as a vital stain. $J$. Cell Biol., 46, 626-631.

Erlandsen, S. L., and Chase, D. G. (1972). Paneth cell function: phagocytosis and intracellular digestion of intestinal microorganisms. 1. Hexamita munis. J. ultrastruct. Res., 41, 296-314.

Erlandsen, S. L., and Parson, J. A. (1973). Immunochemical localization of lysozyme in the small intestine of man using the unlabelled antibody enzyme method. (Abstr.) J. Histochem. Cytochem., 21, 405.

Finch, S. C., Lamphere, J. P., and Jablon, S. (1964). The relationship of serum lysozyme to leukocytes and other constitutional factors. Yale J. biol. Med., 36, 350-360.

Fink, M. E., and Finch, S. C. (1968). Serum muramidase and granulocyte turnover. Proc. Soc. exp. Biol. (N.Y.), 127, 365-367.

Fleming, A. (1922). On a remarkable bacteriolytic element found in tissues and secretions. Proc. roy. Soc. B, 93, 306-317.

Ghoos, Y., and Vantrappen, G. (1970). The cytochemical localization of lysozyme activity in leucocytes. Histochem. J., 2, 11-16.

Ghoos, Y., and Vantrappen, G. (1971). The cytochemical localization of lysozyme in Paneth cell granules. Histochem. J., 3, 175-178.

Glynn, A. A. (1968). Lysozyme: antigen, enzyme and antibacterial agent. In The Sci. Basis Med. Ann. Rev. 31-52.

Glynn, A. A., and Parkman, R. (1964). Studies with an antibody to rat lysozyme. Immunology, 7, 724-729.

Greenwald, R. A., Josephson, A. S., Diamond, H. S., and Tang, A. (1972). Human cartilage lysozyme. J. clin. Invest., 51, 2264-2270.

Greenwald, R. A., and Sajdera, S. W. (1971). Extracellular localisation of lysozyme in rachitic rat cartilage. Proc. Soc. exp. Biol. (N.Y.), 142, 924-927.

Klockars, M., and Osserman, E. F. (1974). Localization of lysozyme in normal rat tissues by an immunoperoxidase method. J. Histochem. Cytochem., 22, 139-146. 
Kuettner, K. E., Eisenstein, R., Soble, L. W., and Arsenis, C. (1971). Lysozyme in epiphysial cartilage. IV. Embryonic chick cartilage lysozyme, its localization and partial characterization. J. Cell Biol., 49, 450-458.

Osserman, E. F., and Lawlor, D. P. (1966). Serum and urinary lysozyme (muramidase) in monocytic and monomyelocytic leukemia. J. exp. Med., 124, 921-952.

Scholnik, A. P., and Kass, L. (1973). A direct cytochemical method for the identification of lysozyme in various tissues. J. Histochem. Cytochem., 21, 65-72.

Speece, A. J. (1964). Histochemical distribution of lysozyme activity in organs of normal mice and radiation chimeras. J. Histochem. Cytochem., 12, 384-391.

Syrén, E., and Raeste, A. M. (1971). Identification of blood monocytes by demonstration of lysozyme and peroxidase activity. Acta haemat. (Basel), 45, 29-35.

Sternberger, L. A., Hardy, P. H., Jr., Cuculis, J. J., and Meyer, H. G. (1970a). The unlabeled antibody enzyme method of immunohistochemistry: preparation and properties of soluble antigen- antibody complex (horseradish peroxidase-antihorseradish peroxidase) and its use in identification of Spirochetes. $J$. Histochem. Cytochem., 18, 315-333.

Sternberger, L. A., Osserman, E. F., and Seligman, A. M. (1970b). Lysozyme and fibrinogen in normal and leukemic blood cells: a quantitative electron immunocytochemical study. John Hopk med. J., 126, 188-209.

Taylor, C. R. (1974). The nature of Reed-Sternberg cells and other malignant 'reticulum cells'. Lancet, 2, 802-807.

Taylor, C. R., and Burns, J. (1974). The demonstration of plasma cells and other immunoglobulin-containing cells in formalin-fixed paraffin embedded tissues using peroxidase-labelled antibody. J. clin. Path., 27, 14-20.

Taylor, C. R., and Mason, D. Y. (1974). The immunohistologica detection of intracellular immunoglobulin in formalin-paraftin sections from multiple myeloma and related conditions using the immunoperoxidase technique. Clin. exp. Immunol., 18. 417 429 . 